\title{
Stakeholder Engagement in Monitoring and Evaluation and Performance of Literacy and Numeracy Educational Programme in Public Primary Schools in Nairobi County, Kenya
}

\author{
Stela Silas Karimi ${ }^{1}$, Angeline Sabina Mulwa ${ }^{2} \&$ Dorothy Ndunge Kyalo ${ }^{3}$ \\ ${ }^{1} \mathrm{PhD}$ Candidate, Project Planning and Management, Department of Open Learning, University of Nairobi, \\ Kenya \\ ${ }^{2}$ Senior Lecturer and Coordinator Online Studies School of Open \& Distance Learning, University of Nairobi, \\ Kenya \\ ${ }^{3}$ Professor and Dean School of Open \& Distance Learning, University of Nairobi, Kenya \\ Correspondence: Stella Silas Karimi, PhD Candidate, Project Planning and Management, Department of Open \\ Learning, University of Nairobi, Kenya. Tel: 254-722-580-003. E-mail: karimisilas@yahoo.com
}

Received: January 20, 2020 Accepted: May 2, 2020 Online Published: June 10, 2020

doi:10.5539/jedp.v10n2p10 URL: http://doi.org/10.5539/jedp.v10n2p10

\begin{abstract}
Kenya's education has faced by many challenges especially in literacy and numeracy skills since the introduction of free primary education. This was contributed by swelling of enrollment in classrooms hence low performance of literacy and numeracy skills. The purpose of this article is to establish the extent to which stakeholder engagement influence performance of literacy and numeracy educational programme in public primary schools in Nairobi County, Kenya. Despite various efforts by key educational stakeholders to improve learner's performance, minimal achievement have been experienced on learner's skills. This study adapted descriptive research survey design and correlational research design. Data collected from the respondents by use of questionnaires and interview schedules from a target population of 2053 and a sample size of 335. Data was analyzed using SPSS version 25 and results presented in tables and figures. Arithmetic mean and standard deviation generated from the descriptive data and Pearson moment correlation coefficient (r) were computed. The coefficient of determination $\mathrm{R}^{2}$ is 0.480 this is an indicator that $\mathrm{R}^{2}$ was the coefficient of determination of this model and it depicted that stakeholder engagement explained $48 \%$. The remaining $52 \%$ was explained by other factors. The overall $\mathrm{F}$ statistics 257.949 with $\mathrm{p}-0.000^{\mathrm{b}}<0.05$ implying a statistical significant relationship between stakeholder engagement and performance of literacy and numeracy educational programme. Interpretations were done and recommendations were policy makers should embrace the methodology of engaging all the stakeholders in programme. This was an indication of strong positive relationship between Stakeholder engagement and performance of literacy and numeracy educational programme. The results showed that stakeholder engagement for monitoring and evaluation strongly influenced the performance of literacy and numeracy educational programme as shown by a correlation coefficient, which was statically significant. Learners should explore more things on their own in order to make predictive answers. Recommendations for further research on participatory monitoring and evaluation practices, which was lacking and specifically involvement of all the stakeholders in the intervention programme in basic education.
\end{abstract}

Keywords: stakeholder engagement, monitoring and evaluation, literacy and numeracy educational programme, performance

\section{Introduction}

Performance of any programme depends wholly on stakeholder engagement especially identification process, level of stakeholder involvement and participation in carrying out the projects activities, which is very important in any organization so as to yield good results. The involvement of all the stakeholders in the programme at different levels helps them advocate that they are the main beneficiaries of the project. Stakeholder involvement means bringing people together and resources in order to help them work as a team. This is to enable them achieve the set goals and objectives of the project while realizing the agreed end (Bartle, 2007). To have successful results all the stakeholders in education and funding agencies should be committed in their work in the process of implementing 
the intervention project.

Stakeholder engagement revolves around the questions on who, why, when and where will the activities be done. How are they are supposed to be done while putting every stakeholder on board in their respective teams according to (Donaldson \& Lipsey, 2006). In primary schools, Head Teachers are supposed to create good learning environment by involving every stakeholder in education at school level in order to recognize their interests and ability in contributing to making decisions in the school context delivery.

Stakeholders involved in a project can either be individuals or groups of people who have a stake at the programme and have some expectations that good outcome will be on their favor. They also have an influence either negatively or positively according to Newcombe (2003) and Freeman (1984) in the project. They continue to argue that stakeholders could be external or internal all expecting benefits from the project. Stakeholder's engagement main corncern is the desire to see the performance of there projects. This so since, proper participation and involvement in every level makes them have confidence and feel part of the project being implemented. Engagement of stakeholders helps in solving project problems and getting more funding or assets of the projects as posited by Rodriguez-Melo \& Mansouri (2011) and Greenwood (2007), stated stakeholder engagement is a practice usually undertaken by organizations so as to put each stakeholder on board in a positive way so as to participant in the activities of the organization.

From the empirical reviewed, the influence of stakeholder engagement established that collaboration among the stakeholders in education improves the quality of education and the learning skills. Collaboration in setting the objectives, developing monitoring and evaluation plans and implementing changes where necessary. Implementation and measurement of education quality improves the projects and increases the likelihood of policy, hence effectiveness in meeting the beneficiaries and donors needs thus sustainability of the programme in future. Therefore the study is to establish the extent to which stakeholder's engagement influence performance of literacy and numeracy educational programme in public primary schools in Nairobi County, Kenya. To what extent does stakeholder engagement influence performance of literacy and numeracy educational programme in public primary schools in Nairobi County, Kenya? On this view stakeholder engagement is very vital in every project.

\section{Literature Review}

Performance of any programme depends on the commitment of stakeholder's involvement and any absence of this means that the project is going to fail. Projects comprise of defined set objectives, which need achievement at a certain time. They should be within budget, quality and safety according to Ika (2012), though despite all this requirements put, stakeholder engagement in many institutions and organizations is ad hoc. Many institutions or organizations don't adhere to this concern of invovlving every stakeholder hence failures experienced in some areas of major concern. Lack of proper and timely funding affects the programme performance.

Performance of literacy and numeracy educational programme depends entirely on stakeholder's engagement especially teachers who are the main implementers of the programme. If they are not fully engaged in all the activities of the programme then low performance in learning process is experienced. There was a national survey conducted and found out that most learners in grade three were not able to infer meaning from a short text (Wasanga, Ogle, \& Wambua, 2010). Similar assessment were done and concurred that learners might have an access to school but little learning was going on (Mugo, Kaburu, Limboro, \& Kimutai, 2011; Onsomu, Nzomo, \& Obiero, 2005; Piper, 2010; Piper \& Mugenda, 2012). In connection to this Uwezo (2014) in a report of assessing if really 'Are our children learning?' the results in this report revealed that engagement of stakeholders like teachers was not fully exhausted since most teachers were absent from school and did not attend to the learners regularly. Also an household survey assessment Uwezo (2016) showed that there was no improvement of literacy despite more than 25 intervention projects sine 2010-2014 across Kenya and this means Nairobi inclusive. The report showed that Nairobi County had the highest number of absenteeism with only $58 \%$ teachers in schools compared to other Counties who ranged from $85 \%$ and above of teachers present. So the learners in Nairobi County most of the times they are left unattended hence low performance in learning skills which needs keen supervision from the teachers. In terms of literacy and numeracy performance among grade one to three learners the situation is not very encouraging since some learners are not able to read the lower grade work effectively neither be able to recognize some letters in their own grades comfortably. So in this regard, Kenya has several projects with major objectives of helping in improving the quality of education through boosting literacy and numeracy skills in grades one to three. Despite this programme being in place, the learner's performance in these skills are not encouraging thus needs to address the gap immediately as aslo foudd by Kibui (2014). The engagement of all the stakeholders in utilizing the results are not clear hence the need to investigate the influence of stakeholder engagement performance of literacy and numeracy educational programme as argued by (Piper \& Mugenda, 2012). Participatory monitoring and 
evaluation process plays very vital position in ensuring that Monitoring and Evaluation activities have achieved project outcomes and gauging project performance cannot be understated. Assesement of learners in class is very important but if it is not well conducted then little is achieved as arqued by Lusweti (2014). Despite several efforts made by educational stakeholders to facilitate learner's skill production, through inserting monetary assets for making better institutions infrastructure, to prepare favorable learning environment, to surpass entry to schooling and eligible educators, tendency of learner's performance is still low and needs immediate attention as it was found by (Stephanie \& Sabrina, 2014;Trunder \& Piper, 2014). Performance of literacy and numeracy educational programme depends entirely on proper supervision from the government officials on a regular basis to avoid laxity from the teachers. Similar observations were made by (Mugo, Mwoma, \& Limboro, 2011), on an yearly studying evaluation report dubbed 'Are our children learning?' revealed that engagement of stakeholders had almost the same findings, in Nairobi County teachers are absent due to one reason or another hence comprising the learning of the leaners outcome. Other studies have mainly focused on factors affecting free primary education and performance of national exams. Specifically performance of mathematics and science in class eight exams but very few have examined the performance of literacy and numeracy educational programme, with combination of English, Kiswahili and Mathematics in lower grades in public primary schools. Identification of stakeholders in education is very vital and key in the performance of literacy and numeracy educational programme but this could be lacking due to so many challenges facing education sector in the country. The process of identifying stakeholders triggers the course of investigation, which leads in getting better influence and power of those involved in education projects. Newcombe (2003) posits that the projects owners are often many-headed creatures who feels better on the ownership of any project and literacy and numeracy programme are no exception however, this is inadequate in Kenya. Low performance of this programme maybe experienced due those heading this programme might not have the right skills or lack of cimmitement in handling the progrmamme. Stakeholder level of involvement through capacity building is very important in any organization since it helps the staff in acquiring new skills and gain confidence on whatever they do. On this regard, teachers could be in short of these skills.

Teachers could be lacking adequate skills in delivering the content of mathematics and languages, which are very involving. In addition, lack of intergrating new methodologies applied through Participatory Monitoring and Evaluation process as posited by Piper and Mugenda, (2012), hence need to advance ways and methods in education sector by involving all stakeholders in learning process in formulation of policies and curriculum development. In a school environment, there are many challenges posed by high ratio of pupils to teachers making it hard for teachers to perform well in delivering the content therefore low performance are experienced. Ministry of education might not be fully involved in supervision of teacher's thus low involvement of all stakeholders in developing education project objectives. At the same time monitoring and evaluation plan are very important in making any programme a success and this could be missing or ignored to be just paper work in this sector. Currently the national government and non-governmental organizations have joined in implementing an intervention programme in public and private primary schools in order to cub the menace of low performance of literacy and numeracy skills. This will enable the government to have an insight of what is required in order to help the lower grade learners in getting better skills and become better citizens who have confidence and courage on carrying out there day to day activities.

Stakeholder engagement and identification process must be clear in any project since it is a crucial exercise, which needs adequate time, accuracy and selection of key players in the project according to Olander (2007), in order to avoid low performance of literacy and numeracy skills in learning process. Rodriguez-Melo and Mansouri (2011) and Greenwood (2007) argue that engagement of stakeholders helps in solving project problems hence improves the outcome and leads to ownership of the project to the parties concerned. They also help in getting more funding and get access to more resources of the projects. If this is not well articulated, then poor results are experienced.

The importance of involving stakeholders is normally critical but for the case of education key stakeholders like teachers are not selected by merit and invovld in curriculum formulation as stressed by chege (2011) and Muiga, (2015). This was supported by an intervention programme of literacy and numeracy undertaken in western Kenya, where the teachers struggled to implement the programme hence leading to no impact or negative results (Lucas et, al., 2014) They argue that stakeholder participation means empowering development beneficiaries in terms of resources and needs identification, planning on the use of resources and the actual implementations of development initiatives. In the first instance, the process have to be managed with great care since too much involvement of stakeholders could lead to a disaster while minimal involvement also could lead to evaluators dominating the process (Patton, 2008).

Major projects involved in the intervention process of literacy and numeracy programme are TUSOME and EGMA in primary schools in the country. The main aim of the programme is to involve all stakeholders in the 
learning process. At the same time in intervening and implementating the same in order to curb the already existing menace of low levels of performance of projects according to (Piper \& Mugenda, 2012; Piper \& Spratt, 2017; Brombacher, Batcherlder, Mulcahy-Dunn, Downs, Nordstrum, King, Cummiskey and Davidson, 2014). By doing this they will solve a problem of effective communication, being innovative, proactive, and prioritization of activities in the projects. The involvement of stakeholders determines the integration and corncern of designing and collaborating them in project development EL-Gohary et al. (2006) and communicating effectively among themselves.

The engagement process may take place at different levels depending on the project. For the case of the current study, the engagement of stakeholders varies from one segment to another whereby the level of engagement changes over time as the implementation of the project progresses. For the case of teachers and pupils, being involved as some of the stakeholders is very vital and several studies have been carried out on the same but having detersive opinions.

As posited by Ngatia (2016) on institutional determinants of PM\&E system implementation among community based development projects in Kibera slums Kenya, he found out that resources allocation, institutional accountability, management support, staff competency have a great influence on PM\&E system implementation for any project to succeed. So for this educational project to be a success all the concerned stakeholders should be fully on board, timely allocation of resources and funds for quick and effective implementation of the programme.

A gap in this study, lack of proper participation of all the participants yield poor results and projects failure in implementation. Involvement of stakeholders needs to go past usage or gift of free work and money commitments to reach out to approach choices. Individuals need to appreciate fundamental flexibilities in order to have the capacity to openly convey what needs be and to build up their maximum capacity in zones of their own decision. Long (2009) noted that acknowledgment and support for more prominent association of nearby individuals points of view, learning needs and aptitudes displays a contrasting option to benefactor driven and pariah drove development. Findings were, without proper engagement of stakeholder's leads to failure of projects performance. Participatory Monitoring and Evaluation process is not just a matter of using participatory techniques within a conventional monitoring and evaluation setting but a more comprehensive way of doing things. It is about radically rethinking who initiates and undertakes the process, and who learns or benefits from the findings (IDS, 1998).

Nationally and international education policy makers have increasingly focused on quality and what children do well in school and if these skills learnt are helpful after leaving school (Wagner, Murphy, \& de Korne 2012). The emphasis is evident on the new sustainable development goals adapted in 2015, goal number four that ensure inclusive and equitable quality education and promote lifelong learning targeting the highest number by 2030 ensuring that all the youth and a substantial adult achieve literacy and numeracy skills (United Nations, 2015). These assessment tools used in learning institutions are instrumental in education transformation and boosting positive productivity while maintaining high performance in literacy and numeracy (Hanushek \& Kimko, 2000) hence helping every individual to acquire self-confidence and reliance.

The level of involvement in learning process lacks clarity on delivery of learning materials therefore little attainment, hence majority laying below the poverty line. Engagement of teachers in learning process is wanting in Nairobi County since absenteeism for both learners and teachers are experienced in schools. In the opinion of the researcher according to the findings, those who had low level of education are the ones who found it difficult in accepting the change since it involved a lot of research and knowledge application, which was lacking to some of them. There is need to organize research courses from the government and proper motivation given to those involved in research as a way of encouragement.

\subsection{Theoretical Framework}

The study anchored on stakeholder theory.

\subsubsection{Stakeholder Theory}

Theoretical framework has a combination of different well-organized ideas with a purpose of breaking down of variables and investigating a certain phenomenon in a particular area bringing up several variables together, related to one another (Kothari, 2004).

Stakeholder theory was grounded on the work of Barnard. Freeman did his first publication in 1984 in San Francisco and believed to be the father of stakeholder theory based on strategic management, corporate planning, systems and organizational theories. Stakeholder theory is based on argument of Mitchell, Agley and Wood (2007), which stated that an agency relationship is a contract under which one or more persons engages another to perform 
some service on their behalf. Stakeholder participation theory has a role in development of policy-making and implementation. The interpretation of participation differences depends on which aspect the emphasis has. Thus, contribution into decision-making process influences implementation and performance of the projects into tangible inputs and outcomes that benefit the beneficiaries. The relationship of stakeholder theory and the variables under study is that, there is full participation of stakeholders in the planning process in participatory monitoring and evaluation process and performance of the projects.

There are different outcomes that are expected from alternative course of action and people will evaluate that which is best for them as posited by (Heikkila \& Gerlak, 2005). Stakeholder theory is mainly concerned with participation of every key participant in the project to give ideas and views about what they intend to achieve, the outcomes of their activities, formulation of policies and implementation of the set objectives and goals.

It is widely used by policy makers, development agencies and academicians. The goals and objectives of the practitioners and purpose of stakeholder participation visualized influencing the interpretation of data collection hence generating constructive information. The results used in making corrective decisions and making changes where necessary in the programme and the institutions concerned.

Selection of monitoring and evaluation tools are measured and analysed with the help of this theory in that it is used for identification, initiatives and utilization of the findings. Participation of stakeholders in different levels link up with the theory in that when stakeholders are developing projects objectives and monitoring and evaluation plans are stickily guided by the theory. This stakeholders theory has a link with this study in that, when the assigned stakeholders who are responsible in data collection and especially selection of monitoring and evaluation of data instruments, collation of information, schedules of monitoring and evaluation plan activities fully participate in the activities. Mulongo, (2013) concur with this theory, involving all the stakeholders is very vital since most of the information is shared and tools sued are appropriate since they designed by the same people. However, Kiptum, Mandela and Murira (2018) differ with the earlier statement that involving stakeholder's full yield good result. In their opinion for any good to be realized, there must be a conducive environments that will influence the productivity and satisfaction of the activity performed in any level. This study found out that not only the said elements improve learning but that there are many factors that contribute to soomth learning as indicated in the findings of this study. Stakeholder theory deals with the institutional management and ethics, which deals with moral and values affecting planning and management in schools. This could be directly or indirectly and how the schools manages the relationships amongst parents, learners, teachers, policy makers in education and funding organizations according to Freeman and Daniel (2007). Steps and activities incorporated the performance projects is experienced and then theory of change is profound. 


\subsection{Conceptual Framework}

The study conceptual framework is in figurelbelow.

\section{DEPENDENT VARIABLE}

\section{INDEPENDENT VARIABLE}

\section{Stakeholder's Engagement for M\&E}

- Identification of stakeholders

- Stakeholders' level of involvement

- Developing of project objectives

- Developing monitoring and evaluation plan

\section{Performance of Literacy and Numeracy} Educational Programme

- Reading skills

- Simple arithmetic calculation skill

- Letter recognition

- Beneficiary Satisfaction

- Proficiency skills in listening of literacy and numeracy skills

- Proficiency skills in speaking of literacy and numeracy skills

- Proficiency skills and writing

- Timely Acquisition of literacy and numeracy skills

- Transition rate improved

- Class average performance improved

Figure 1. Conceptual Framework of Influence of Stakeholder Engagement in Monitoring and Evaluation and Performance of Literacy and Numeracy Educational Programme

\section{Methodology}

The study article used pragmatism paradigm, which is non-committal structure of philosophy in real life. In this regard, pragmatism tends to apply mixed methods research, which provides a more comprehensive approaches for collecting and analyzing data rather than using only one way of either qualitative or quantitative (Creswell and Plano, 2011). According to Migiro and Magangi (2011) states that mixed methods research encourages researchers to use multiple approaches to collecting and analyzing data within a single study, recognizing the limitations of using a single method. In this study, quantitative data was collected using structured questionnaires whilst qualitative data was collected using interview schedules.

The study adapted descriptive research survey design and correlational research design. According to Cooper and Schindler (2006), a descriptive survey research design study is concerned with finding out the what, where and how of a phenomenon. Correlational research design was to help in getting the direction and strength of the relationships between stakeholder engagement and performance of literacy and numeracy of education progamme.

The unit of analysis were ongoing and completed literacy and numeracy educational programme, while the unit of inquiry included Head Teachers, Lower Primary School Teachers, the Curriculum Support Officers and officers Research Triangle International Institutes.

A sample size of 335 respondents was arrived using Yamane formula of 1967 from a target population of 2053, while data collected from the respondents through questionnaires and interview schedules. Purposive sampling employed to 33 Head Teachers, 3 curriculum support officers and 5 Research Triangle International Institutes officers who had an in-depth information pertaining to study constructs, while 294 lower public primary school teachers selected through simple random sampling from 1800 teachers.

Data collected was both qualitative and quantitative data, crosschecked for correctness, coded and analyzed on thematic areas. Quantitative data was analyzed through employing descriptive and inferential statistics generated thus the descriptive results were presented in tabular forms using, frequencies, arithmetic means and standard deviation while inferential statistics were obtained using Pearson's Product Moment correlation while F-test was used to test hypotheses. 
Both qualitative and quantitative data explained the influence of stakeholder engagement and performance of literacy and numeracy educational programme exhaustively. After collection activity, the researcher edited, coded categorized, checked all the blank responses and keyed in the information into SPSS program version 25 for actual analysis to be carried out. The data subjected to Normality test, done through checking and found to follow normal distribution.

Pearson's Product Moment correlation coefficient(r) described the strength of relationship between the independent predictor variable and dependent variable. The test carried out on a two-tail test since it allowed for either influence to the positive or negative direction while hypothesis testing tested at $95 \%$ level of confidence and significance level of .0 .05 . The hypothesis with linear relationship analyzed using simple regression analysis and Pearson's Product Moment Correlation used for interpretation of results. Together with simple graphics analysis, descriptive statistics form the basis of virtually every quantitative analysis to data. Correlation analysis to establish the relationship between the independent and dependent variables employed.

Interpretation of the results for the linear relationships of this study was based on; for a weak correlation $\mathrm{r}$ ranging from +0.10 to +0.29 ; moderate correlation between +0.30 to +0.49 ; while strong correlation from +0.50 to +1.0 (Shirley, Stanley, \& Daniel, 2005). Hence, $\mathrm{r}=0.63$ implies a positive strong relationship between stakeholder engagement and performance of literacy and numeracy educational programme.

\section{Results}

The main goal of the study was to establish the extent to which stakeholder's engagement influence performance of literacy and numeracy educational programme in public primary schools in Nairobi County, Kenya. Total number of questionnaires were 335 delivered to the respondents only 281, filled and returned representing a response rate of $84 \%$ generally representative enough to analysis and generalization of results to the population. The results are in tandem with studies by Richardson (2005) who states that a return rate of $50 \%$ is sufficient

\subsection{Overall Descriptive Analysis of Performance of Literacy and Numeracy Educational Programmes}

As pertains to performance of literacy and numeracy educational programme the respondents were subjected to several statements to solicit their opinions on a likert scale of 1-5 whereby; Strongly disagree(SD)=1, Disagree $(\mathrm{D})=2, \operatorname{Neutral}(\mathrm{N})=3$,Agree $(\mathrm{A})=4$ and Strongly Agree $(\mathrm{SA})=5$ as depicted on Table 1 .

Table 1. Performance of Literacy and Numeracy Educational Programme

\begin{tabular}{|c|c|c|c|c|c|c|c|}
\hline $\begin{array}{l}\text { Performance of literacy and } \\
\text { numeracy } \\
\text { programme statements }\end{array}$ & $\begin{array}{l}\text { SD } \\
\text { F } \\
(\%)\end{array}$ & $\begin{array}{l}\text { D } \\
\text { F } \\
(\%)\end{array}$ & $\begin{array}{l}\mathbf{N} \\
\mathbf{F} \\
(\%)\end{array}$ & $\begin{array}{l}\text { A } \\
\text { F } \\
(\%)\end{array}$ & $\begin{array}{l}\text { SA } \\
\text { F } \\
(\%)\end{array}$ & Mean & $\begin{array}{l}\text { Std. } \\
\text { Deviatio } \\
\text { n }\end{array}$ \\
\hline $\begin{array}{l}\text { 1.There is improvement in } \\
\text { reading learning skills of the } \\
\text { pupils due to the operation of } \\
\text { this programme }\end{array}$ & $\begin{array}{l}4 \\
(1.4 \%)\end{array}$ & $\begin{array}{l}65 \\
(23.2 \%)\end{array}$ & $\begin{array}{l}27 \\
(9.6 \%)\end{array}$ & $\begin{array}{l}136 \\
(48.4 \%)\end{array}$ & $\begin{array}{l}49 \\
(17.4 \%)\end{array}$ & 3.57 & 1.070 \\
\hline $\begin{array}{l}\text { 2.There is improvement in } \\
\text { simple arithmetic calculations } \\
\text { skills of the pupils due to the } \\
\text { operation of this programme }\end{array}$ & $\begin{array}{l}4 \\
(1.4 \%)\end{array}$ & $\begin{array}{l}63 \\
(22.4 \%)\end{array}$ & $\begin{array}{l}32 \\
(11.4 \%)\end{array}$ & $\begin{array}{l}117 \\
(41.6 \%)\end{array}$ & $\begin{array}{l}65 \\
(23.2 \%)\end{array}$ & 3.63 & 1.111 \\
\hline $\begin{array}{l}\text { 3.Learners improved in } \\
\text { recognition of alphabet letters } \\
\text { due to the operation of this } \\
\text { programme }\end{array}$ & $\begin{array}{l}4 \\
(1.4 \%)\end{array}$ & $\begin{array}{l}57 \\
(20.3 \%)\end{array}$ & $\begin{array}{l}40 \\
(14.2 \%)\end{array}$ & $\begin{array}{l}126 \\
(44.8 \%)\end{array}$ & $\begin{array}{l}54 \\
(19.3 \%)\end{array}$ & 3.60 & 1.058 \\
\hline $\begin{array}{l}\text { 4.Programme beneficiaries are } \\
\text { satisfied with the benefits }\end{array}$ & $\begin{array}{l}2 \\
(0.7 \%)\end{array}$ & $\begin{array}{l}59 \\
(21.0 \%)\end{array}$ & $\begin{array}{l}44 \\
(15.7 \%)\end{array}$ & $\begin{array}{l}104 \\
(37.0 \%)\end{array}$ & $\begin{array}{l}72 \\
(25.6 \%)\end{array}$ & 3.66 & 1.097 \\
\hline $\begin{array}{l}\text { 5.Listening learning skills was } \\
\text { enhanced through the operation } \\
\text { of the programme }\end{array}$ & $\begin{array}{l}7 \\
(2.5 \%)\end{array}$ & $\begin{array}{l}48 \\
(17.1 \%)\end{array}$ & $\begin{array}{l}58 \\
(20.6 \%)\end{array}$ & $\begin{array}{l}161 \\
(57.3 \%)\end{array}$ & $\begin{array}{l}7 \\
(2.5 \%)\end{array}$ & 3.40 & 0.886 \\
\hline
\end{tabular}




\begin{tabular}{|c|c|c|c|c|c|c|c|}
\hline $\begin{array}{l}\text { 6.Speaking learning skills was } \\
\text { enhanced through the operation } \\
\text { of the programme }\end{array}$ & $\begin{array}{l}2 \\
(0.7 \%)\end{array}$ & $\begin{array}{l}53 \\
(18.5 \%)\end{array}$ & $\begin{array}{l}52 \\
(18.5 \%)\end{array}$ & $\begin{array}{l}168 \\
(59.8 \%)\end{array}$ & $\begin{array}{l}6 \\
(2.1 \%)\end{array}$ & 3.44 & 0.843 \\
\hline $\begin{array}{l}\text { 7. Writing learning skills was } \\
\text { enhanced through the operation } \\
\text { of the programme }\end{array}$ & $\begin{array}{l}4 \\
(1.4 \%)\end{array}$ & $\begin{array}{l}51 \\
(18.1 \%)\end{array}$ & $\begin{array}{l}50 \\
(17.8 \%)\end{array}$ & $\begin{array}{l}169 \\
(60.1 \%)\end{array}$ & $\begin{array}{l}7 \\
(2.5 \%)\end{array}$ & 3.44 & 0.865 \\
\hline $\begin{array}{l}\text { 8. Transition rate of learners has } \\
\text { increased }\end{array}$ & $\begin{array}{l}15 \\
(5.3 \%)\end{array}$ & $\begin{array}{l}54 \\
(19.2 \%)\end{array}$ & $\begin{array}{l}23 \\
(8.2 \%)\end{array}$ & $\begin{array}{l}47 \\
(16.7 \%)\end{array}$ & $\begin{array}{l}142 \\
(50.5 \%)\end{array}$ & 3.88 & 1.352 \\
\hline $\begin{array}{l}\text { 9.The class average } \\
\text { performance has improved }\end{array}$ & $\begin{array}{l}19 \\
(6.8 \%)\end{array}$ & $\begin{array}{l}50 \\
(17.8 \%)\end{array}$ & $\begin{array}{l}20 \\
(7.1 \%)\end{array}$ & $\begin{array}{l}143 \\
(50.9 \%)\end{array}$ & $\begin{array}{l}49 \\
(17.4 \%)\end{array}$ & 3.54 & 1.168 \\
\hline $\begin{array}{l}\text { 10.Acquisition of literacy and } \\
\text { numeracy within times was } \\
\text { experienced while undertaking } \\
\text { the programme }\end{array}$ & $\begin{array}{l}2 \\
(0.7 \%)\end{array}$ & $\begin{array}{l}52 \\
(18.5 \%)\end{array}$ & $\begin{array}{l}40 \\
(14.2 \%)\end{array}$ & $\begin{array}{l}176 \\
(62.7 \%)\end{array}$ & $\begin{array}{l}11 \\
(3.9 \%)\end{array}$ & 3.50 & 0.859 \\
\hline Composite Mean and SD & & & & & & 3.56 & 0.995 \\
\hline
\end{tabular}

As shown in Table 1, there were 10 statements generated enough data on performance of literacy and numeracy educational. The means of these statements summed were up and used to compute the composite mean and standard deviation that resulted to 3.56 and 0.995 respectively. Statements with means below the composite mean considered to influence the performance negatively whilst statements with means above the composite mean influenced performance positively.

Generally, there was great improvement upon the operationalization of the programme and the intervention has significantly helped the learners who were involved in the programme and teachers who trained on the new methodology. Simple arithmetic calculation skills, alphabetical letter recognition skills, enhancement of reading skills, satisfaction of the beneficiaries, and general performance of all the learners in class improved. Transition level to another grade was excellent according to the findings since it was a government requirement that all learners should proceed to the next class. However, there were areas which needed more effort to be applied for example help learners on how to comprehend what they have learned. This also means that if the learners were not able to comprehend what they have read then simple calculation would be a problem. Most learners have slightly improved on speaking skill and could be able to pronounce the letter sounds correctly even without the help of the teacher but a few had a problem on the mix up of the first language and the second language. Writing skills enhanced through the operation of the programme but more practice is required. Due to the introduction of the new methods and additional of resources for example textbooks and other reading materials great improvement on learners is experienced. Acquisition of literacy and numeracy within time did not influence performance of literacy and numeracy educational programme positively but had better results before the intervention of the programme.

The interviews schedule conducted revealed that, differing information on performance of the programme with few cases on some learners. Some below average in reading skills despite the allocation of new text books as pointed by one Curriculum Support Officer "Most learners who were not able to attend school in regular basis can now attend classes without interference since most of them have been provided with text books and writing material by the government and the implementing organization."

The interviews also revealed that the teachers were still relying on the old teaching methods whereby they have not embraced the new methodology, "Teachers have ignored the usage of new textbooks hence follows the old methodology of self-centered instead of learner centered. Frequent visits to classroom should be embraced so as to encourage the teachers to adapt new teachers guide given by TUSOME which has the new methodologies of teaching these skills. " Research Triangle Institute Monitoring and Evaluation Officers

The interview with the Curriculum Support Officer collaborated with the quantitative results who indicated that:

"Listening, speaking and writing skills has been enhanced since many learners have their own text books and can be able to at least do some practice of the work taught in the absences of the teacher." Curriculum Support Officer Langata Sub-County

Interview with Research Triangle Institute Monitoring and Evaluation Officers indicated that class average 
performance had significantly improved. However, more practice needed so that implementation cab be a reality:

"More materials like textbooks for both learners and teachers guides which have been distributed to schools have really helped in improving the learning skills but more emphasis should be put into the usage of new methodology." Research Triangle Monitoring and Evaluation Officers.

\subsection{Overall Descriptive Analysis of Stakeholder Engagement in Monitoring and Evaluation}

Stakeholder's engagement in any project is vital, especially when trying to identify those who will be involved in the project and there power of influence in the project. The responses presented in Table 2.

Table 2. Stakeholders Engagement and Performance of Literacy and Numeracy Educational programme

\begin{tabular}{|c|c|c|c|c|c|c|c|}
\hline Statements & $\begin{array}{l}\text { SD } \\
\text { F } \\
(\%)\end{array}$ & $\begin{array}{l}\text { D } \\
\text { F } \\
(\%)\end{array}$ & $\begin{array}{l}\mathrm{N} \\
\mathrm{F} \\
(\%)\end{array}$ & $\begin{array}{l}\text { A } \\
\text { F } \\
(\%)\end{array}$ & $\begin{array}{l}\text { SA } \\
\text { F } \\
(\%)\end{array}$ & Mean & $\begin{array}{l}\text { Std. } \\
\text { Deviation }\end{array}$ \\
\hline \multicolumn{8}{|l|}{ Stakeholder identification } \\
\hline $\begin{array}{l}\text { 1. Stakeholders are carefully } \\
\text { identified and listed }\end{array}$ & $\begin{array}{l}5 \\
(1.8 \%)\end{array}$ & $\begin{array}{l}63 \\
(22.4 \%)\end{array}$ & $\begin{array}{l}33 \\
(11.7 \%)\end{array}$ & $\begin{array}{l}131 \\
(46.6 \%)\end{array}$ & $\begin{array}{l}49 \\
(17.5 \%)\end{array}$ & 3.56 & 1.075 \\
\hline $\begin{array}{l}\text { 3. Needs assessments was } \\
\text { conducted to involve the views } \\
\text { and areas of interest of key } \\
\text { stakeholders }\end{array}$ & $\begin{array}{l}6 \\
(2.1 \%)\end{array}$ & $\begin{array}{l}65 \\
(23.1 \%)\end{array}$ & $\begin{array}{l}25 \\
(8.9 \%)\end{array}$ & $\begin{array}{l}131 \\
(46.6 \%)\end{array}$ & $\begin{array}{l}54 \\
(19.3 \%)\end{array}$ & 3.58 & 1.106 \\
\hline \multicolumn{8}{|l|}{ Stakeholder level of involvement } \\
\hline $\begin{array}{l}\text { 4. Stakeholders were involved } \\
\text { in the development of } \\
\text { curriculum development }\end{array}$ & $\begin{array}{l}7 \\
(2.5 \%)\end{array}$ & $\begin{array}{l}63 \\
(22.4 \%)\end{array}$ & $\begin{array}{l}29 \\
(10.3 \%)\end{array}$ & $\begin{array}{l}122 \\
(43.4 \%)\end{array}$ & $\begin{array}{l}60 \\
(21.4 \%)\end{array}$ & 3.59 & 1.128 \\
\hline $\begin{array}{l}\text { 5.The government officials } \\
\text { from the MOEST were involved } \\
\text { in supervising teachers }\end{array}$ & $\begin{array}{l}10 \\
(3.6 \%)\end{array}$ & $\begin{array}{l}61 \\
(21.7 \%)\end{array}$ & $\begin{array}{l}21 \\
(7.5 \%)\end{array}$ & $\begin{array}{l}129 \\
(45.9 \%)\end{array}$ & $\begin{array}{l}60 \\
(21.3 \%)\end{array}$ & 3.60 & 1.149 \\
\hline $\begin{array}{l}\text { 6.RTI International officers } \\
\text { participated in funding and } \\
\text { training the stakeholders } \\
\text { involved in the programme }\end{array}$ & $\begin{array}{l}7 \\
(2.5 \%)\end{array}$ & $\begin{array}{l}60 \\
(21.4 \%)\end{array}$ & $\begin{array}{l}30 \\
(10.7 \%)\end{array}$ & $\begin{array}{l}137 \\
(48.8 \%)\end{array}$ & $\begin{array}{l}47 \\
(16.6 \%)\end{array}$ & 3.56 & 1.078 \\
\hline \multicolumn{8}{|l|}{ Developing of project objectives } \\
\hline $\begin{array}{l}\text { 7.stakeholders participated in } \\
\text { setting objectives which are } \\
\text { SMART }\end{array}$ & $\begin{array}{l}5 \\
(1.8 \%)\end{array}$ & $\begin{array}{l}60 \\
(21.4 \%)\end{array}$ & $\begin{array}{l}39 \\
(13.9 \%)\end{array}$ & $\begin{array}{l}130 \\
(46.3 \%)\end{array}$ & $\begin{array}{l}47 \\
(16.6 \%)\end{array}$ & 3.55 & 1.058 \\
\hline $\begin{array}{l}\text { 8.The objectives set were } \\
\text { SMART and according to the } \\
\text { programme }\end{array}$ & $\begin{array}{l}10 \\
(3.6 \%)\end{array}$ & $\begin{array}{l}55 \\
(19.6 \%)\end{array}$ & $\begin{array}{l}34 \\
(12.1 \%)\end{array}$ & $\begin{array}{l}136 \\
(48.4 \%)\end{array}$ & $\begin{array}{l}47 \\
(16.6 \%)\end{array}$ & 3.54 & 1.088 \\
\hline \multicolumn{8}{|l|}{ Developing M\&E Plans } \\
\hline $\begin{array}{l}\text { 9.M\&E plans were developed } \\
\text { by all the stakeholders in the } \\
\text { program }\end{array}$ & $\begin{array}{l}5 \\
(1.8 \%)\end{array}$ & $\begin{array}{l}50 \\
(17.7 \%)\end{array}$ & $\begin{array}{l}44 \\
(15.7 \%)\end{array}$ & $\begin{array}{l}139 \\
(49.5 \%)\end{array}$ & $\begin{array}{l}43 \\
(15.3 \%)\end{array}$ & 3.59 & 1.007 \\
\hline $\begin{array}{l}\text { 10.We involved all the } \\
\text { stakeholders in literacy and } \\
\text { numeracy programme }\end{array}$ & $\begin{array}{l}5 \\
(1.8 \%)\end{array}$ & $\begin{array}{l}56 \\
(19.9 \%)\end{array}$ & $\begin{array}{l}38 \\
(13.5 \%)\end{array}$ & $\begin{array}{l}110 \\
(39.1 \%)\end{array}$ & $\begin{array}{l}72 \\
(25.7 \%)\end{array}$ & 3.67 & 1.115 \\
\hline Composite mean and SD & & & & & & 3.59 & 1.102 \\
\hline
\end{tabular}

As shown in Table 2, the overall composite mean was 3.59 and the standard deviation was 1.102. 
Obtained on this line item was a mean score of 3.56 and standard deviation of 1.075 that were both slightly below the composite mean of 3.59 and standard deviation of 1.102. This implies that opinions gathered were converging. It also implies that the process of stakeholder identification lacked carefulness in doing it and that there is need for improvement on this aspect if at all performance in literacy and numeracy educational programme can be a reality. Lack of enough interaction with the teachers involved in the programme hence low performance in the outcome since most teachers needed enough guidance from the officers. "Lack of frequent supervisor from the ministry has made has made teachers to have laxity hence low performance. This has been contributed to few officers who are already overwhelmed by too many administrative responsibilities". Research Triangle Officer

In the Second statement, the results showed a mean score of 3.65 and standard deviation of 1.201 this was above the overall composite mean of 3.59 and standard deviation of 1.102. It is clear from this results that that selection of stakeholders ensured that gender parity experienced. This could be because of Kenya constitution that emphasize on a third of opposite gender in every working place.

On the third statement, mean score of 3.58 and standard deviation of 1.106, against the composite mean of 3.59 and standard deviation of 1.102. The opinions were converging suggesting that needs assessment positively involved the views of the key stakeholders. Lack or inadequate assessment of needs is likely to lead to mix-prioritization of goals and hence poor performance of the programme. Scholars like Walker, Shelly and Bourne (2008) hold the view that stakeholders should be fully involved in the project and conduct needs assessment meaning they also concurred with the current study that all stakeholders should be involved in the needs assessment process for better results.

The fourth statement obtained a mean score of 3.59 and standard deviation of 1.128 same as the composite mean of 3.59 and standard deviation of 1.102 , implying that development of curriculum development involves the stakeholders.

A fifth statement mean score for this line item was 3.60 against a composite mean score of 3.59 implying that supervision of teachers during implementation of the programme involved government officials from the ministry of education. Standard deviation was 1.149 above the composite standard deviation of 1.102 indicating that opinions were rather divergent. It is evident that good performance is associated with proper supervision that should be encouraged in all stages of implementing educational programme to yield better results.

The sixth statement had a mean score of 3.56, which was below the composite mean of 3.59 while the seventh statement, mean score was 3.55 against a composite of 3.59 suggesting that stakeholders never got a chance to participate in setting SMART objectives hence they did not influence the performance of literacy and numeracy educational programme positively. This informs us that any deviation or challenges experienced in the performance of literacy and numeracy programme could be objectives did not reflect the opinions many stakeholders. Therefore, there is need to ensure full participation of all stakeholders in planning and designing of objectives in order to improve implementation of educational programme. Witnessed from this result was also a much lower standard deviation of 1.058 against 1.083 indicating that opinions were convergence.

On the eighth statement, mean score for this line item was 3.54 and standard deviation of 1.088 against a composite 3.59 and standard deviation of 1.083 suggesting that set objectives did not influence the performance of literacy and numeracy educational programme positively.

On the ninth statement, mean score of 3.59 and standard deviation of 1.007 obtained which matched the composite mean 3.59 and standard deviation of 1.102. This implied that averagely the programme encouraged all stakeholders to participate in developing plans for Monitoring and Evaluation hence influence on performance of literacy and numeracy educational programme. A lower standard deviation of 1.007 against a composite standard deviation of 1.102 obtained suggesting opinions remained convergent.

The tenth statement had a higher mean score of 3.67 computed against 3.59 composite mean. Thus, all stakeholders got involved in literacy and numeracy educational programme and standard deviation of 1.115 obtained against 1.102 implying that opinions were inconsistent. This shows that for any programme to be a success, full support and implementation process should bring on board all the stakeholders concerned in planning so as promote the principle ownership.

All in all the results of the variable indicated that Stakeholder identification process careful procedures else need for improvement on this aspect if at all performance has to be realized in literacy and numeracy educational programme. The level of how stakeholders and specifically teachers engagement is quite scanty and needs improvement for programme to achieve its objectives. Supervision of teachers during implementation of the programme needs to monitor. 
Most stakeholders never got a chance to participate in setting SMART objectives. Therefore, the deviation or challenges experienced in the performance of literacy and numeracy educational programme could be, objectives do not reflect the opinions of majority stakeholders. Therefore, there is need to ensure full participation of all stakeholders in planning and designing of objectives in order to improve implementation of educational programme.

The results of interview schedule from key informants showed that stakeholder engagement influenced performance of literacy and numeracy educational programme. The results of the interviews were consistent with the quantitative data.

\subsection{Correlation between Stakeholder's Engagement and Performance of Literacy and Numeracy Educational Programme}

A correlation analysis conducted to establish the direction and the magnitude of the relationship between performance of literacy and numeracy education programme and stakeholder engagement for monitoring and evaluation. The results of correlation analysis presented in Table 3.

Table 3. Correlations Matrix between Stakeholder's Engagements, Performance of Literacy, and Numeracy Educational Programme

\begin{tabular}{|c|c|c|c|}
\hline \multirow{2}{*}{$\frac{\text { Variables }}{\text { Performance of literacy and }}$} & \multicolumn{3}{|c|}{ Performance of literacy and numeracy educational program Stakeholder engagement } \\
\hline & Pearson Correlation & 1 & $0.693^{* *}$ \\
\hline \multirow{3}{*}{$\begin{array}{l}\text { numeracy } \\
\text { programme }\end{array}$} & Sig. (2-tailed) & & 0.000 \\
\hline & $\mathrm{n}$ & 281 & 281 \\
\hline & Pearson Correlation & $0.693^{* *}$ & 1 \\
\hline \multirow[t]{2}{*}{ Stakeholder engagement } & Sig. (2-tailed) & 0.000 & \\
\hline & $\mathrm{n}$ & 281 & 281 \\
\hline
\end{tabular}

${ }^{\text {** }}$ Correlation is significant at the 0.05 level (2-tailed).

Given a Pearson correlation of 0.693 , a strong positive relationship between stakeholder engagement and performance of literacy and numeracy educational programme existed. Thus $(\mathrm{r}=.0 .693, \mathrm{p}<0.05)$. As correlation however does not mean causality, therein a regression analysis conducted to verify if there is a statistical relationship between stakeholder engagement and performance of literacy and numeracy educational programme

\subsection{Inferential Analysis of Performance of Literacy and Numeracy Education Programme and Stakeholder Engagement for Monitoring and Evaluation}

The following hypothesis were tested using linear simple regression model to satisfy the objective.

i) $\mathrm{H}_{0}$ Stakeholders engagement has no significant influence on performance of literacy and numeracy educational programme in public primary schools in Nairobi County, Kenya.

ii) Stakeholders engagement has significant influence on performance of literacy and numeracy educational programme in public primary schools in Nairobi County, Kenya.

The mathematical model that used for testing the null hypothesis was linear regression model as depicted in Table 4.

$\mathrm{y}=\mathrm{a}+\mathrm{b}_{1} \mathrm{X}_{1}+\varepsilon$

Where:

$y \quad$ - Performance of literacy and numeracy educational programme

$X_{I}$ - Stakeholder engagement

$b_{1}$ - Regression coefficient

a - Regression constant

$\varepsilon \quad-\quad$ Error term 
Table 4. performance of literacy and numeracy educational programme

\begin{tabular}{|c|c|c|c|c|}
\hline \multicolumn{5}{|c|}{ Model Summary } \\
\hline Model & $\mathrm{R}$ & $\mathrm{R}$ square & Adjusted R Square & $\begin{array}{l}\text { Std. Error of the } \\
\text { Estimate }\end{array}$ \\
\hline & $0.693 a$ & 0.480 & 0.479 & 0.62326 \\
\hline
\end{tabular}

a. Predictors: (Constant) Stakeholder engagement for monitoring and evaluation

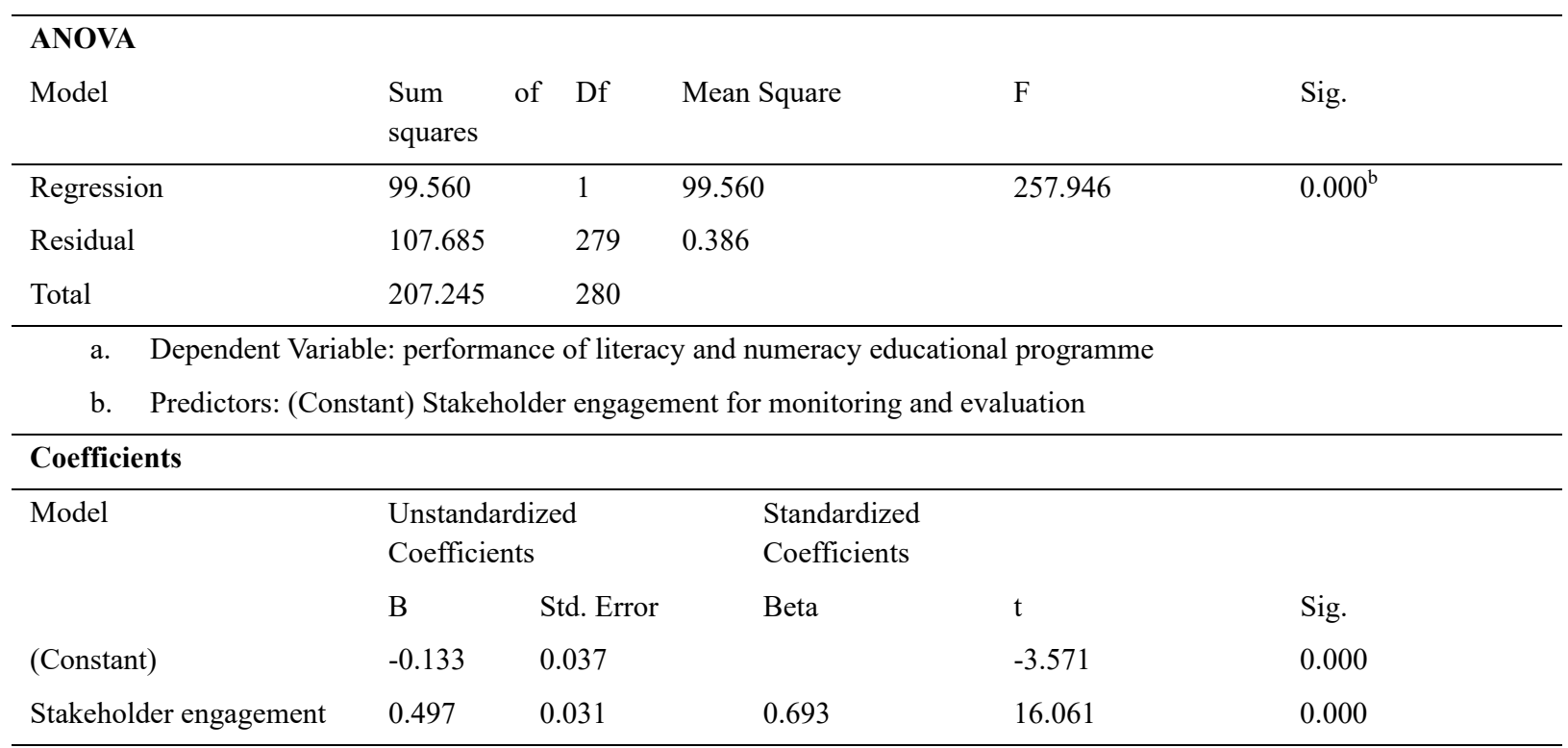

Model: $(\beta=0.497, \mathrm{t}=16.061, \mathrm{p}=0.000<0.05)$.

Predictor Variable: Stakeholder Engagement.

Dependent Variable: Performance of Literacy and Numeracy Educational Programme.

In Table 4 stakeholder's engagement has statistically significant influence on performance of literacy and numeracy educational programme $(\beta=0.497, \mathrm{t}=16.091, \mathrm{p}=0.000<0.05)$ implying that stakeholder engagement had a significant influence on performance of literacy and numeracy educational programme

The assessment of the test of coefficient of R-squared is 0.480 and $r=0.693$. This demonstrates that stakeholder engagement strongly influenced performance of literacy and numeracy educational programme by 0.480 , implying that stakeholder engagement explained $48 \%$ of variations in the performance of literacy and numeracy educational programme in public primary schools in Nairobi County, Kenya. Therefore, there are other factors, which could influence the performance of literacy and numeracy educational programme, which explained by the remaining percentage $52 \%$.

From Table 4, a positive beta coefficient for Stakeholder engagement is 0.479 suggesting a direct relationship exists as per the model implying there was a positive significant relationship between

Stakeholder engagement and performance of literacy and numeracy educational programme at $5 \%(\mathrm{p}=0.000)$ level of significance.

The overall F-statistic is 257.949 with a p-value of $0.000<0.05$ which implies that there was a statistical relationship between stakeholder engagement and performance of literacy and numeracy educational programme. Based on the research findings, therefore we reject the null hypothesis that states; $\boldsymbol{H}_{0:}$ : Stakeholders engagement has no significant influence on performance of literacy and numeracy educational programme in public primary schools in Nairobi County, Kenya. The conclusion made in the study meant that Stakeholders engagement has a significant influence on performance of literacy and numeracy educational programme in public primary schools in Nairobi County, Kenya. Using the statistical findings in table 4 the regression model equation obtained from this output thus substituted:

$y=-0.133+0.497 X_{1}+e$

Where: 
$y \quad$ - Performance of literacy and numeracy educational programme

$X_{I} \quad-\quad$ Stakeholder engagement for M\&E

The findings of the first objective linked to the previous empirical investigations that reviewed earlier on. Stephanie and Sabrina (2014) focused on stakeholder analysis and engagement in projects, from stakeholder relational perception to stakeholder ontology. It determined that inappropriate social interaction between project stakeholders caused project failures. This supported lusweti (2014), who assessed literacy intervention of school improvement programme on lower primary school pupils. The study determined that stakeholder engagement has significant influence on performance of literacy and numeracy educational programme. The findings of this study were that every stakeholder in learning has a role to play and therefore they can all influence the performance of L\&N educational programme.

The study established that stakeholder engagement as part of participatory Monitoring and Evaluation had an influence on the performance of the literacy and numeracy educational programme. The study findings further showed that the existence of a strong positive linear correlation between stakeholder engagement for Monitoring and Evaluation and performance of literacy and numeracy programme. The implication of these results clearly indicates that by engaging the stakeholders in leaning process through indicators such as identification of stakeholders, stakeholder level of involvement, developing of project objectives and developing monitoring and evaluation plans, finally makes stakeholders part of the project intervention and highly enhances performance of literacy and numeracy educational programme.

It is evident that from the statements on quantitative data, the means of the line items were below the composite mean of stakeholder engagement variable. This implies that there is need to engage all stakeholders at all stages of implementation of the programme in Monitoring and Evaluation whereby they should fully be involved in developing project objectives and developing monitoring and evaluation plans so that there can be improvement on learning of pupils as far as literacy and numeracy is concerned. Similarly, identification of stakeholders and level of involvement is fair although it still needs more improvement to ensure performance of literacy and numeracy educational programme achieved as intended, not forgetting the project intervention aspects such as resource allocation and monitoring of all programme activities. To sum up, stakeholder engagement for Monitoring and Evaluation remains very crucial if at all educational programme have to attain the set objectives.

In relation to the foregoing comparable studies, the current study has adduced empirical evidence in support of their earlier findings, despite no similar studies have been conducted in Nairobi County, Kenya. The study found out that other studies investigated parental involvement in schools instead of literacy and numeracy educational programme.

\section{Acknowledgements}

I would like to extend my sincere appreciation to several people and institutions that contributed in one way or another towards this study. Foremost to my supervisors Dr. Angeline Sabina Mulwa and Professor Dorothy Ndunge Kyalo for their invaluable exemplary and sincere guidance, constant encouragement, patience, and expertise.

My sincere and special gratitude goes to Professor Charles Mallans Rambo who has been my mentor on this journey of my study. His sincere encouragement and support is recommendable. University of Nairobi for giving me opportunity to learn, my lectures and classmates. Family members especially my children Mutwiri, Gacheri and their father Njui who made this study a reality.

\section{References}

Bartle, P. (2007). Participatory Management: Methods to Increase Staff Input in Organizational Decision Making. Retrieved on January 112020 from http://cec.vcn.bc.ca/cmp/modules/pm-pm.htm

Brombacher, A., Batchelder, K., Mulcahy-Dunn, A., Dick, A., Downs, P., Nordstrum, L. ... Davidson, M. (2014) Assessment of School Quality for Education and WASH in three regions of Mainland Tanzania namely Mbeya, Iringa, and Njombe. A report prepared by RTI International for UNICEF, Tanzania

Chambers, R. (1997). Who's Reality Counts: Putting the Last First? Intermediate Technology Publications. https://doi.org/10.3362/9781780440453.000

Chege, M. P. (2011). Effects of School Based Teacher Development (SBTD) programme on teaching-learning process in public primary school in Makuyu Division, Kenya. Doctoral dissertation, Uni-versity of Nairobi, Nairobi, Kenya. 
Cooper, D. R., \& Schindler, P. S. (2006). Business Research Methods. Business Research Methods ( $9^{\text {th }}$ ed.). Thousand Oaks, California.

Creswell, J. W., \& Plano Clark, V. L. (2011). Designing and Conducting Mixed Methods Research (2nd ed.). London: Sage Publications Ltd.

Donaldson, S. I., \& Lipsey, M. W. (2006). Roles for theory in contemporary evaluation practice: Developing practical knowledge. In I. Shaw, J. Greene, \& M. Mark (Eds.), The Handbook of Evaluation: Policies Programs, and Practices (pp.56-75). London: Sage. https://doi.org/10.4135/9781848608078.n2

El-Gohary, N., Osman, H., \& El-Diraby, T. (2006). Stakeholder management for Public Private Partnerships. International Journal of Project Management, 24(7), 595-604. https://doi.org/10.1007/s10551-007-9509-y

Freeman, R. E. (1984). Strategic Management: A stakeholder approach. Marshfield, MA: Pitman Books.

Freeman, R. E., \& Daniel R. G., Jr. (2007). Corporate Strategy and the Search for Ethics. Englewood Cliffs, N.J.: Prentice-Hall.

Greenwood, M. (2007). Stakeholder Engagement: Beyond the Myth of Corporate Responsibility. Journal of Business Ethics, 74(2007), 315-327. https://doi.org/10.1257/aer.90.5.1184

Hanushek, E A., \& Kimko, D. D. (2000). Schooling, labor force quality, and the growth of nations. American Economic Review 90(5), (December), 1184-1208. https://doi.org/10.1257/aer.90.5.1184

Heikkila, T., \& Gerlak, A. K. (2005) the formation of large-scale collaborative resource management institutions: clarifying the roles of stakeholders, science, and institutions. The Policy Studies Journal, 3(4), 583-612. https://doi.org/10.1111/j.1541-0072.2005.00134.x

Ika, L. A. (2012). Project management for development: In Africa why projects are failing and what can be done about it. Project Management Journal, 43 (4), 27-41. https://doi.org/10.1002/pmj.21281

Institute of Development Studies (IDS). 1998. Participatory Monitoring and Evaluation: Learning From Change. Policy Briefing Issue 12 November 1998. https://www.ids.ac.uk/files/dmfile/PB12.pdf

Kibui, A. W. (2014). Language policy in Kenya and the New Constitution for Vision 2030. International Journal of Educational Science and Research, 4(5), 89-98

Kiptum. J. K., Mandela. R. O., \& Murira. F. N. (2018). An Assessment of How Work Environment Influence Teachers' Satisfaction in Elgeyo Marakwet County. The International Journal of Humanities and Social $\begin{array}{llll}\text { Studies, } & 6(6), & 265-272 . & \text { Retrieved }\end{array}$ http://internationaljournalcorner.com/index.php/theijhss/article/view/131257/90909

Kothari, C. R. (2004). Research Methodology-Methods and Techniques. New Delhi: New Age International Limited Publishers.

Long, R. (2009). Research methodology: A step by step for beginners. London: Sage Publication.

Lucas, A. M., McEwan, P. J., Ngware, M., \& Oketch, M. (2014). Improving early-grade literacy in East Africa: Experimental evidence from Kenya and Uganda. Journal of Policy Analysis and Manage-ment, 33(4), 950-976. https ://doi.org/10.1002/pam.21782

Lusweti, C. N. V. (2014). Assessing reading to learn literacy intervention of school improvement programme on lower primary school pupils" literacy skills in Kwale district. Retrieved on September 52019 from http://erepository.uonbi.ac.ke/handle/11295/74080

Migiro, S. O., \& Magangi, B. A. (2011). Mixed Methods: A Review of Literature and the Future of the New Research Paradigm. African Journal of Business Management, 5(10), 3757-3764. https://doi.org/10.3138/9781442673496-014

Mitchell R. K., Agle B. R., \& Wood D. J. (1997). Toward a theory of Stakeholders Identification and Salience: Defining the Principles of who and what really Counts. Academy of Management Review, 22(2), 833-886. https://doi.org/10.3138/9781442673496-014

Mugo, J. K., Mwoma, T. B., \& Limboro, C. M. (2011). Teaching for Improved Learning, A Classroom Observation and communication. Study Report of a WERK/World Bank Study, November 2011.

Mugo, J., Kaburu, A., Limboro, C., \& Kimutai, A. (2011).Are our children learning? Annual learningassessment report. Nairobi, Kenya: Uwezo.

Muiga, M. J. (2015). Factors influencing the use of monitoring and evaluation systems of public projects in 
Nakuru County. University of Nairobi. Retrieved from http://erepository.uonbi.ac.ke/handle/11295/90407

Mulongo, G. (2013). Effects of active learning teaching methodology on learner participation. A Journal of Education and Practice, 4(4), 157-168. Retrieved from https://pdfs.semanticscholar.org/1cb8/e4667700c76cac51b54ae27acf7675119f49.pdf

Newcombe, R. (2003). From client to project stakeholders: A stakeholder mapping approach. Construction Management and Economics, 21(8), 841-848. https://doi.org/10.1080/0144619032000072137

Ngatia, C. N. (2016). Institutional determinants of participatory monitoring and evaluation systems implementation among community based development projects in Kibera slum, Kenya. Retrieved from http://erepository.uonbi.ac.ke/handle/11295/99327

Olander, S. (2007). Stakeholder impact analysis in construction project management. Construction Management and Economics, 25(3), 277-287. https:// doi.org/10.1080/01446190600879125

Onsomu, E., Nzomo, J., \& Obiero, C. (2005). The SACMEQ II Project in Kenya: A study of the condi-tions of schooling and the quality of education. Harare and Nairobi: SACMEQ and Kenya Ministryof Education, Science and Technology.

Patton, M. Q. (2008). Utilization-focused evaluation (4th ed.). Thousand Oaks, CA: Sage.

Piper, B. (2010). Kenya Early Grade Reading Assessmentfindings report. Research Triangle Park. NC: RTI International and East African Development Consultants.

Piper, B., \& Mugenda. (2012). The Primary Math and Reading Initiative: Baseline Report. Prepared for USAID/Kenya under the education data for decision-making (EdData II) project, task order no. AID-623-M-11-00001. Research Triangle Park, North Carolina, USA: RTI International. http://pdf.usaid.gov/pdf_docs/pa00hx75.pdf

Piper, B., \& Spratt, J. (2017). Cambodia teacher professional development policy options brief. Prepared for the United States Agency for International Development (USAID)/Cambodia under All Children Reading - Asia (ACR-Asia), All Children Reading - Cambodia, Contract No. AID-OAA-TO-16-00017, REQ-ASIA-16-00017. Research Triangle Park, NC: RTI International. Retrieved from http://pdf.usaid.gov/pdf_docs/PA00N2RT.pdf.

Richardson, J. T. E. (2005). Instruments for obtaining student feedback: A review of the literature. Assessment \& Evaluation in Higher Education, 30(4), 387-415. https:// doi.org/10.1080/02602930500099193

Stephanie, M., \& Sabrina, L. F. (2014). Stakeholder analysis and engagement in projects: From stakeholder relational perspective to stakeholder relational ontolog. International Journal of Project Management, 32(7), 1108-1122. https://doi.org/10.1016/j.ijproman.2014.02.010

United Nations. (2015). Transforming our world: The 2030 agenda for sustainable development. United Nations, New York. (2015). Retrieved from https://sustainabledevelopment.un.org/post2015/transformingourworld/publication

Uwezo. (2014). Are Our Children Learning? Literacy and Numeracy in Kenya 2014. Nairobi: Twaweza East Africa. https://palnetwork.org/wp-content/uploads/2016/01/Kenya-2014.pdf

Wagner, D. A., Murphy, K. M., \& de Korne, H. (2012). Learning first: A research agenda for improving learning in low-income countries. Washington, DC: Brookings Institution.

Wasanga, P. M., Ogle, A. M., \& Wambua, R. M. (2010). Report on monitoring of learner achievementfor class 3 in literacy and numeracy. Nairobi, Kenya: Kenya National Examinations Council.

Yamane, T. (1967). Statistics: An introductory analysis. New York: Harper \& Row.

\section{Copyrights}

Copyright for this article is retained by the author(s), with first publication rights granted to the journal.

This is an open-access article distributed under the terms and conditions of the Creative Commons Attribution license (http://creativecommons.org/licenses/by/4.0/). 